\title{
Scientific Conferences as Way to Develop Students' Foreign Language Communicative Competence
}

\author{
Yuliya Savinova*1, Tatiana Akhmetzyanova ${ }^{1}$, Svetlana Pozdnyakova ${ }^{2},{\text { Ekaterina } \text { Dvorak }^{2} \text {, and Zhanna Zarutskaya }}^{1}$ \\ ${ }^{1}$ Department of Foreign Languages in Engineering, Nosov Magnitogorsk State Technical University, 455000 Magnitogorsk, \\ Russia \\ ${ }^{2}$ Department of Foreign Languages for Technical Specialties No.2, Irkutsk National Research Technical University, 664000 \\ Irkutsk, Russia
}

\begin{abstract}
The issues of the student engagement in science-related activities and the development of students' language communicative competence are especially relevant in a technical university, where due to the prevailing of the Sciences, the professional communicative competence has become increasingly vital. The goal of this article is to examine how interdisciplinary scientific conferences for students held in foreign languages can foster the foreign language communicative competence of students. In the article, we present the definition and the three basic models of communicative competence. A method of pedagogical observation is used that represents comprehension and analysis of goal-oriented preparation of students for practical scientific conferences. We reveal the fact that interdisciplinary scientific conferences for students held in foreign languages allow educators to foster the foreign language communicative competence of students and deepen their knowledge in professional area, as well as to equip them with research skills since students' participation in the conferences increases their attention and focus, motivates them to practice critical thinking skills of high level.
\end{abstract}

\section{Introduction}

Nowadays, the engagement of students in science-related and research activities is the actual task of educators and research scientists involved in the university educational process. This provides students with the possibility to foster their creative abilities in the various forms of their professional activity, to stimulate the desire to deepen knowledge, to search required information, and to form analytical, prognostic, and communicative skills, as well as to cultivate their professional and personal qualities.

Students' research activity appears to be one of the main directions of improving the content and structure of engineering education and a necessary component that characterises a professional person. The development of the ways to stimulate students' research activities enabling the release and use of their creative and intellectual potential contributes to a more successful professional education as a whole. When students are engaged in science education, which is relevant to their lives and their future professional activity, they are goaloriented in acquiring research skills that facilitate students' personal development thus promoting readiness for future professional activity, as well as the adaptation process to their future profession.

Our university experience shows that a large part of students has either low or undeveloped communicative competence that proves the necessity for its further development.

Consequently, the development of foreign language communicative competence is the task requiring extra attention and solution. One of the effective ways to solve the problem can be the organisation of student scientific conferences held in foreign languages.

The aim of the article is to describe the method and check its efficiency. Indeed, without developed communication skills, a university graduate sometimes finds it difficult to adapt to the professional environment: to establish contacts with colleagues at work, memorise a large amount of information, process information, transfer it to others, etc.

Therefore, we firmly believe that the development of students' foreign language communicative competence is an unresolved problem both in theory and in practice. This fact convincingly proves the need to give this issue proper attention and work at further development of students' foreign language communicative competence.

\subsection{Communicative competence: existing models}

The term "competence" has been introduced in modern linguistics by Chomsky [1]. Campbell and Wales [2] proposed the term "communicative competence", while

* Corresponding author: savinova_july@mail.ru 
Canale and Swain [3] presented one of the three core models of the communicative approach to foreign language teaching that is most widely used.

We find it appropriate to name each of the three basic ones. The first comprehensive model of communicative competence was elaborated by Canale \& Swain who defined communicative competence as knowledge of language and its use in actual and meaningful communication circumstances. They divided the competence into four components:

1. discourse competence;

2. grammatical competence;

3. sociocultural competence;

4. strategic competence.

Bachman [4] and Palmer [5] proposed another model of communicative competence. It comprised two main categories with subcategories:

1. organisational knowledge (textual and grammatical knowledge);

2. pragmatic knowledge (lexical, functional and sociocultural knowledge.

Strategic competence in Bachman and Palmer [5] model is the knowledge of language, which interacts with metacognitive strategies, such as assessment, goalsetting and planning. [6]

In 1995, Celce-Murcia, Dörnyei \& Thurrel [7] proposed a communicative competence model with five components:

1. discourse competence;

2. linguistic competence;

3. actional competence;

4. sociocultural competence;

5. strategic competence.

We hold the view that for the context of our research, the first communicative competence model is the most appropriate one since it comprises all competences necessary for adequate communication in foreign languages.

\subsection{Communicative competence: our vision}

Undoubtedly, the communicative competence has a complex meaning, and thus obliges a personality to demonstrate the effective binding "a thought - an action", intellectual inversion; the personality should have a strong character for continuous self-development and readiness for interaction. We support the point of view expressed by Savignon [8], who considered communicative competence as the ability to function in a truly communicative setting, and described it as interaction between people for negotiation of meaning.

Nowadays, it is crucial to be able to express oneself in a foreign language, using linguistic and paralinguistic skills, be understood and communicate with other people at a decent level. [9]

The developed communicative competence is an essential feature of a personality, which contributes to vital needs and effective work. Its main components may include communicative activity, confidence, volume, and needs. [10] Speaking about the role of the communicative competence in the personal socialisation, it should be pointed out that it is an important prerequisite for effective adaptation in the closest community. [11]

The decreased communicative competence causes a decline in communication activity (narrowing the social network, selectivity in communication, introverting and self-isolation), and stronger emotional reaction to the social impact, dissatisfaction with various interpersonal relations. Without proper communicative skills, a university graduate is unable to adapt to the professional community, to engage with colleagues, to remember and process a large volume of information and so on. During the process of communicative competence development, all communicative abilities of a student, his/her communicative literacy and culture undergo qualitative changes.

Considering the problem comprehensively, the reserves of the personality cannot be denied: I-concept, reflection, setting targets and their achievement, life perspective and values the personality should have. Inner reserves of the human mental state play an important role in the development of students' foreign language communicative competence, their self-development, and self-improvement.

Thus, communicative competence may be considered as the willingness to take part in interpersonal relationship. Undoubtedly, a student who is focused on communication will develop his/her communicative competence quicker. We hold the view that foreign language communicative competence refers to the ability to interact with other people for negotiation of meaning in foreign languages.

\subsection{Interdisciplinary scientific conferences for students as one of the most effective way to develop their communicative competence and engage them in science-related education}

Obviously, interdisciplinary scientific conferences for students held in foreign languages allow educators to foster the foreign language communicative competence of students and deepen their knowledge in professional area, as well as to equip them with research skills since students' participation in the conferences increases their attention and focus, motivates them to practice critical thinking skills of high level.

Doing science implies discussions when students share their observations, interpret evidence, and explain their findings. The interaction between students that takes place during discussions supports both science learning and the development of foreign language communicative competence. Positive conditions for providing social interaction among students are the key element to language development.

During the discussions held in a foreign language, students should be encouraged to participate in spite of their levels of language proficiency in order to show what they know. There are such situations when students have a lot to say, but they do not have the ability to say it perfectly in English. This results in enhanced 
consciousness of the necessity to develop foreign language communicative competence.

Therefore, we are strongly convinced that the issue of developing foreign language communicative competence of technical university students is timely and relevant.

\section{Problem Statement}

Obviously, a lack of developed foreign language communicative competence of students made it necessary to upgrade their professional communicative skills in foreign languages. This problem is especially relevant in a technical university, where due to the prevailing of the Sciences, the professional communicative training has become increasingly vital.

The reinforcement of the humanitarian component of technical education has always been an issue of primary importance, inasmuch as production of the technogenic type of culture can result in spiritual impoverishment of a personality and dehumanisation of education, when engineers acquire only professional skills and abilities. All this calls for the personal development of a technical specialist, who combines high professionalism with an ability to communicate successfully using foreign languages. Thus, these are the humanities in general, and foreign language study in particular that serve to reveal personal abilities of technical university students, foster their creativity, and develop their communicative competence.

\section{Purpose of the study}

There have been many studies investigating the ways how to develop students' communicative competence, but we are strongly convinced that interdisciplinary scientific conferences for students held in foreign languages are one of the effective ways to develop foreign language communicative competence of engineering students during their studies at the university.

In view of this, the purpose of our research is to examine how interdisciplinary scientific conferences held in foreign languages can influence the development of foreign language communicative competence.

\section{Research methods}

In our research, we used a method of pedagogical observation, which represented comprehension and analysis of goal-oriented preparation of students for practical scientific conferences in foreign languages, during the process of which we received the factual material.

The purpose of our observation was to examine how scientific conferences held in foreign languages can influence the development of foreign language communicative competence of students. Undoubtedly, preparing students for participation in scientific practical conferences in foreign languages is a complex solution of educational, formative and developmental objectives, which we wish to address, taking into consideration the fact that the three objectives are based on a personoriented approach to learning.

\subsection{Educational, formative, and developmental objectives}

Firstly, the following formative objectives can be distinguished: successful professional development, socialisation, and moral development of the individual. When preparing students for the conference, we based our work on cooperative pedagogy technology and tried to teach students the following things:

- to understand the essence and social significance of their future profession and to show a steady interest in it;

- to organise their own activity, taking into account the purpose and the means of its achievement;

- to analyse the results of their activities;

- to work effectively in a team with a supervisor.

Secondly, the educational objectives of student conferences held in foreign languages include the following:

- active involvement of students in scientific activities related to their future profession, teaching them English for specific purposes (sector-specific vocabulary necessary in the context of communication in the area of their professional interests);

- formation of expertise, knowledge and skills while working with foreign language information (text compression for oral public speech, preparation and carrying out multimedia presentation, mastering the art of public speaking, etc.).

Thirdly, the following developmental objectives of student conferences in foreign languages can be distinguished as:

- development of general learning and special skills, self-control and independent work skills;

- forming and developing educational and intellectual expertise, knowledge and skills,

- enhancement of memory, attention, and consequently, foreign language communicative competence.

\subsection{The object of the pedagogical observation}

The object of the pedagogical observation was the process of foreign language communicative competence development of technical university students in the process of their preparation for scientific conferences, whereas the subject of the observation included all participants of the educational process (students and foreign language teachers).

The observation was carried out simultaneously by all scientific advisors of students who have been involved in the process of preparation for the conference and without communicating with each other evaluated their student's level of communicative competence.

The Department of Foreign Languages in Engineering at Nosov Magnitogorsk State Technical University, and the Department of Foreign Languages for Technical Specialties No.2, at Irkutsk National Research 
Technical University were empirical fields of our research. It holds annual scientific practical conferences Foreign Languages in the Sphere of Professional Communication for the first- and second year students of such institutes as Power Engineering, Metallurgy, Mining and Transport, Construction, Architecture and Arts, Mechanical Engineering, Economics and Law, etc. These conferences provide students with a unique chance to master foreign language vocabulary in their fields of studies, and consequently, to develop their foreign language communicative competence.

\subsection{The stages of preparation for scientific conferences}

Before holding scientific conferences, a very scrupulous work consisting of the following stages should be carried out:

1. pre-preparatory stage (search for a theme, collection of information about the theme of the research, literary survey);

2. preparatory stage (literary survey analysis, compression of materials);

3. final stage (correction of the oral speech, preparation of the multimedia presentation).

However, it is hard and labour-intensive work for a student to be done alone, therefore one of his/her foremost challenges is to find a scientific advisor. As practice shows, usually this is their former or present foreign language teacher. Nevertheless, a student can choose any scientific advisor at his/her discretion as well. After the scientific advisor agrees to assist in tutoring a student for participation in the scientific conference, preparation itself starts.

Preparation for the conference is assumed to take 22.5 months, and involves mutual collaboration of educators and students, involving the choice of themes, making and discussion of the reports, solving the problems arisen in the process of mutual work, correcting drawbacks after the scientific advisor's critical remarks.

To define the desired direction of the oral presentation at the conference, the following criteria can be suggested:

- relevance of the problem in question;

- global character of the problem;

- practical orientation and/or enhancement of theoretical knowledge in the student's professional area;

- availability and accessibility of information about the investigated problem in various foreign languages in the internet;

- personal interests of a student (his/her professional interests, experience reflection, practical contribution in the field of the research);

- interest of the audience in the theme of the report.

In view of this, we are convinced that the role of a supervisor in coordinating and monitoring students' activity at all stages of preparation for the practical scientific conference cannot be overemphasised, and in fact, is a major contributing factor to the success of the conference. Being a fully-fledged participant of the conference, a scientific advisor of a student becomes his/her great motivator and coordinator of the entire preparatory process as well.

At the first stage of preparation for scientific conference, students surf the Internet using the key words of their themes, thus collecting the necessary material on sites both in their native and second languages (English, German or French). "Thanks to the extensive use of interactive technologies, most students can easily find the necessary language materials on the Internet, as well as interact with their professional community or with other students" $[12$, p. 80]. This stage is a highly labour-intensive process that takes most of the preparation time. When the search for materials is in progress, the supervisor should advise students to pay attention to materials, which differ in genres of presentation and stylistic nuances. Scientific advisors are supposed to assist students in expressing different opinions concerning the theme of their future report, thus helping them to look at issues, questions, and dilemmas from every angle.

Further, at the second stage of their preparation students inform their scientific advisors of the initial material search for the selected theme, present articles, notes, abstracts from the Internet sites, audio-and video materials in their native and second foreign languages. In close cooperation, they analyse and compare the selected materials. This contributes a lot to the development of foreign language communicative competence, inasmuch as all discussions are conducted in the students' second language. As a result, the whole concept of the future report is drawn up.

The next step is to focus on the correct translation of the report into the second language, which is also made under a careful supervision of the scientific advisor, who controls the correctness of grammar, lexical and stylistic aspects of the report. In the process of the report making, students are taught to use modern on line dictionaries in order to avoid literal translation, which also has a positive effect on the development of their foreign communicative competence. In the end of this stage, students print the final version of their report, which is thoroughly checked and corrected by the supervisor. The main methodological idea ensures that all students' mistakes have to be explained by the teacher in detail and understood by the student.

From our point of view, it is crucially important for supervisors to support students, make them feel relaxed, give recommendations how to behave in front of the audience when they are giving their speech. Due to the fact that for the majority of students, this public presentation is the first official one, at least the one made at such high scientific level. It is vital for supervisors to reduce the students' stress, make a comfortable atmosphere, motivate and praise them so that later in life they become highly competent specialists able to use a foreign language at a level sufficient for communication.

At the third, final stage of the preparation for the scientific conference, the students read out a final version of the report to the scientific advisor, who, in his/her turn records it on a voice recorder to correct pronunciation, pausing, rhythm and pace of the report. 
Alternatively, the scientific advisor can record his/her own voice of the same presentation for the student to take advantage of it later. Thus, students will have at their disposal a good example of expressing emotionally evaluative, discursive, and communicative framework of utterance: introductory words and phrases, ways of expressing emotions and opinions, linguistic means of changing the subject of conversation, etc.

Subsequently, after repeated actions of reading and correction, the student starts his/her preparation of the multimedia presentation keeping in mind the following: the purpose of the presentation, its objectives and outcomes that the audience expects; concentration on a core message; making eye contact with the audience; keeping to a logical flow (introduction, the middle, conclusion); limiting the time of your presentations, etc. At this stage of the preparation for the conference, students also think carefully over questions they may be asked after their presentation speech is over.

One of the suggested methods to go through this is the following: before the conference is held, students make presentations in front of their foreign language group. Afterwards, a language teacher and peers ask them relevant questions, which should be obligatory responded to. This challenging task relieves students' fears and complexes, thus instilling self-confidence and developing their foreign language communicative potential. Another important point to note is that the report at the student conference should contain, on the one hand, materials of scientific character and, on the other hand, be well understood by the general public.

Due to the fact that students studying at the Department of Foreign Languages in Engineering have different majors, their conference reports differ as well. We find it appropriate to list some of the reports presented at the student scientific practical conference of 2017:

-in the field of IT-engineering: Human Intellect Versus Artificial One. Who will win? Cloud Technologies;

- in the field of developing engineering: Smart House Technologies, 3-D Printers for Developing;

- in the field of mechanical engineering: Innovation Technology in Car Battery Charging, Rise of Roboethics;

- in the field of power engineering: New Alternative Sources of Energy, Nuclear Energy Issues; Search for Energy Savings in Glass Producing Regenerative Furnaces;

- in the field of economics: Competitiveness in the XXI Century: How One Can Manage Business Effectively, Improving Personnel Management Efficiency Using Pareto Method;

- in the field of metallurgy engineering: Analysis of Control Methods of the Blast Furnace Lining Wear, Nanotechnology: Pros and Cons, Prospective Applications;

- in the field of mining engineering: Future Prospects of Logistics, Simulation Technologies.

For holding annual student scientific conference, a list with participants' names and their reports was made, as well as a special announcement on the university site to attract public. For efficient time management, the time and the date of the conference were discussed beforehand, and students had to drop their presentations onto the desktop. The conference usually took 4 hours or more depending on the number of participants, with an obligatory break between two parts. The hall of the conference was prepared in advance to check computer settings, loud speakers, projector, screen, sound and picture quality. Undoubtedly, testing the equipment beforehand is essential to verify that it is working as expected, inasmuch as technical difficulties during the conference can throw off the rhythm of the conference. For creating a festive atmosphere, the hall was decorated with posters greeting the members of the conference.

There are two ways to lead the conference - by teachers or students themselves. Allowing students to take the lead of the conference instead of their teachers creates new opportunities for reflection, engagement and agency. It brings to light their very best strengths in conducting conferences in their second language, such as creating the conference agenda in advance, starting and ending the conference, giving the floor to speakers, limiting the time of presentations, making brief and relevant comments, etc. Careful preparation for this is needed to help students feel less anxious. Apparently, student-led conferences encourage them to be more engaged in the student scientific life, and develop their communicative skills and abilities.

\subsection{Criteria of evaluation of scientific reports}

For objective evaluation of the reports, 4-5 university teachers from the Department of Foreign Languages in Engineering were appointed to be the members of the jury, no less than 3 of them - with Ph.D. degrees. A special evaluation table was distributed to them to be filled out for every participant (See Table 1).

Table 1. Criteria of evaluation of scientific reports in foreign language.

\begin{tabular}{|l|c|}
\hline \multicolumn{1}{|c|}{ Criteria } & $\begin{array}{c}\text { Number of } \\
\text { points }\end{array}$ \\
\hline \multicolumn{1}{|c|}{ Scientific aspect - 10 points } \\
\hline $\begin{array}{l}\text { Novelty (level of student's work } \\
\text { independence) }\end{array}$ & 2 \\
\hline Relevance & 2 \\
\hline $\begin{array}{l}\text { Composition, logical structure and } \\
\text { convincing conclusions }\end{array}$ & 2 \\
\hline $\begin{array}{l}\text { Availability (correct use of conceptual } \\
\text { framework) }\end{array}$ & 2 \\
\hline Interdisciplinary approach & 2 \\
\hline \multicolumn{2}{|c|}{ Linguistic aspect - 20 points } \\
\hline Prepared speech & 10 \\
\hline Literacy ideas & 2 \\
\hline $\begin{array}{l}\text { Logic and consistency of } \\
\text { expression }\end{array}$ & 2 \\
\hline Speech expressiveness & 2 \\
\hline Vocabulary \\
\hline Use of terminology \\
\hline
\end{tabular}




\begin{tabular}{|l|c|}
\hline \multicolumn{2}{|c|}{$\begin{array}{c}\text { Unprepared speech (response to questions) - 10 } \\
\text { points }\end{array}$} \\
\hline Literacy & 2 \\
\hline $\begin{array}{l}\text { Logic and consistency of ideas } \\
\text { expression }\end{array}$ & 2 \\
\hline Speech expressiveness & 2 \\
\hline Vocabulary & 2 \\
\hline Use of terminology \\
\hline \multicolumn{2}{|c|}{ Technical aspect - 10 points } \\
\hline $\begin{array}{l}\text { Structure of e-presentation (availability } \\
\text { of the cover page, plan, references, } \\
\text { etc.) }\end{array}$ & 2 \\
\hline $\begin{array}{l}\text { Presentation composition (availability } \\
\text { of video and musical fragments, } \\
\text { animation, etc.) }\end{array}$ & 2 \\
\hline $\begin{array}{l}\text { Style of presentation (combination of } \\
\text { colours, fonts, background, etc.) }\end{array}$ & 2 \\
\hline Consistency of presentation and report & 2 \\
\hline Quality of illustrative material & 2 \\
\hline Total sum & $\mathbf{4 0}$ \\
\hline
\end{tabular}

Every presentation at the student scientific conference had to meet the set requirements for time and content: one speech had to last no more than 10-12 minutes; the report had to contain the introduction with relevance of the problem, the body of the presentation, and conclusions with the student's own point of view to the presented material. After each presentation, members of the jury evaluated it filling out Table 1 . As a result, the total sum of every speaker was calculated (max. 40 points), and the winners announced. Afterwards, they were awarded with certificates and valuable prizes; all participants received published materials of the conference.

\subsection{Forms of engaging students in science- related research activities and communicative competence improvement}

Conventionally, the forms of engaging students in research studies and communicative competence improvement can be divided into two types.

On the one hand, these forms allow students to develop the skills of independent scientific research in the curriculum within the educational process (abstracts, reports, laboratory works, research assignments in class and during the internships, etc.). For instance, a good strategy to improve the students oral English speaking is the assignments that request the students to write down some questions about the topic and then discuss them. [13]

These result in the developed general and special scientific skills of carrying out and generalising the research results, elements of critical thinking and a complex of creative abilities needed for a future specialist, as well as improved communicative competence.

On the other hand, special attention should be given to the student out-of-class independent activity. It should be noted that we introduce some extra curriculum activities in order to participate in interdisciplinary scientific conferences, receiving grants, academic mobility, international internships, writing scientific articles, etc.

\section{Results}

At the end of pedagogical observation, it has been noted by all scientific advisors that the level of their students' communicative competence has largely increased. They could ask and answer questions, explain ideas and concepts, share their thoughts and ideas, record their thoughts and observations and then use them to explore additional ideas. They came to know the ways to deal with foreign language information, acquired second language terms in the area of their professional technical studies, practiced oral language skills.

The students themselves admitted that conferences in foreign language enlarged their communicative ability, made them feel more self-confident and ready to communicate about the area of their future major.

\section{Discussion and Conclusion}

Mutual collaboration of educators and students of the technical university in the process of scientific practical conference preparation creates a situation of real business communication in the framework of their professional technical sphere of communication. Meanwhile students practice and improve their skills of independent educational activity, learn strategies and techniques of retrieving information, summarising and presenting results, related information and compliance findings in an effective way. The participation of students in the conference largely increases their level of oral skills in foreign languages, enables them to master the art of public speaking.

Student scientific practical conference can be considered as a model of oral scientific communication as well, inasmuch as participation in the conference makes it easier for students to prepare and defend their future diploma project in a foreign language, communicate with foreign specialists, pass international exams successfully, and study or work abroad.

Undoubtedly, holding student conferences in foreign languages substantially increases the level of students' foreign language proficiency. They test in practice various communicative strategies and techniques of obtaining, processing, storing, and transferring information in a foreign language (e.g. search for information in various sources, its compression, expansion, memorising, highlighting the main ideas, presenting it to other, etc.). Students become aware of importance of foreign language information interpreting in the sphere of their professional interests.

Moreover, there has been a positive dynamic in terms of social adaptation of students, who acquire teamdeveloping skills, which, in turn, forms their active social and professional position.

Eventually, investing time in student conference preparation ensures a successfully led conference, encourages students to get involved into an absolutely 
new for them process of mutual collaboration with their scientific advisors, assists in revealing their hidden communicative reserves. The organisation of annual student conferences is aimed at developing students' communicative and intercultural potential, teaching them strategies and techniques of making oral presentations, acquiring the vocabulary of their future major and thus, developing their foreign language communicative potential.

It is suggested to apply the methodology of holding student scientific conferences in foreign languages into the practice of extracurricular activities at any university, as the results showed its positive influence on the development of student foreign language communicative competence.

The paper describes one of the possible ways of its development; in further research much attention will be focused on other effective ways.

\section{References}

1. N. Chomsky, Aspects of the Theory of Syntax. (MIT Press, Cambridge, MA, 1965)

2. R. Campbell., \& R. Wales, The study of language acquisition in Linguistics (Penguin Pooks, Harmondsworth, 1970)

3. M. Canale \& M. Swain, Theoretical bases of communicative approaches to second language teaching and testing, Applied Linguistics 1 (1), 1-47 (1980), https: //doi.org/10.1093/applin/1.1.1

4. L.F. Bachman, Fundamental Considerations in Language Testing (Oxford University Press, Oxford, 1990)

5. L.F. Bachman, \& A.S. Palmer, Language Testing in Practice (Oxford University Press, Oxford, 1996)

6. Ç. T. Mart, International Journal of English Linguistics 8 (2), 163-167 (2018)

7. M. Celce-Murcia, Z. Dörnyei, \& S. Thurrel, Issues in Applied Linguistics 6 (2), 5-35 (1995)

8. S. J. Savignon, Communicative Competence: An Experiment in Foreign-Language Teaching (Centre for Curriculum Development, Philadelphia, 1972)

9. Yu.A Ivkina, Developing communicative potential of technical university students (Magnitogorsk Pedagogical Institute, Magnitogorsk, 2002)

10. E.V. Grigorieva, G.F. Kalganova, M.G. Mosolkova, Developing business communicative competence for foreign language learners within the program of additional education, 3rd International Multidisciplinary Scientific Conference on Social Sciences and Arts SGEM 2016, Book 1 Vol. 3, 179186 (2016)

11. S. Soliman, J. Anchor \& D. Taylor, Journal Studies in Higher Education (2018)

12.S.V. Antonova, T.L. Akhmetzyanova, O.P. Benkovskaya, S.K. Voynatovskaya, A.O. Zarutskaya, Zh.N. Zarutskaya, N.N. Masyuk, I.V. Ryabchikov, I.P. Chernaya, Questions of modern science: the collective scientific monograph (Internauka, Moscow, 2017)

13.X. Wei \& Y. Liu, Ways to Improve the Students Communicative Competence. Proceedings of the 2nd International Conference on Green Communications and Networks 2012 (GCN 2012): 1, (2013) 